\title{
ANALISIS MEDIASI PRESTASI BELAJAR PADA PENGARUH KUALITAS LAYANAN TERHADAP KEPUASAN MAHASISWA (STUDI PADA MAHASISWA UNIVERSITAS ISLAM MALANG).
}

\author{
Fuji Santoso \\ Mahasiswa Magister Manajemen Pascasarjana Universitas Islam Malang \\ Email: siregarfuji93@gmail.com
}

\begin{abstract}
Abstrak
Tujuan penelitian ini untuk Menganalisis Mediasi Prestasi Belajar Pada Pengaruh Kualitas Layanan Terhadap Kepuasan Mahasiswa (Studi Pada Mahasiswa Universitas Islam Malang). Dimana Kualitas Layanan sebagai variabel $X$ terdiri dari enam variabel, yaitu Layanan Fisik (tangible), Kehandalan (reability), Ketanggapan (responsive), Jaminan (assurance), Empati (empathy) dan System Informasi. Populasi dalam penelitian ini adalah seluruh Mahasiswa UNISMA. Maka penelitian ini adalah penelitian Kuantitatif, yang menggunakan metode survai dengan mengambil sampel dari suatu populasi dan menggunakan angket atau kuesioner sebagai alat pengumpul data yang utama, dengan jumalah 175 responden. Teknik analisis data dalam penelitian ini menggunakan Uji instumen, Uji Normalitas, Analisis Data, Uji Hipotesis Uji t dan Sobel. software Program SPSS versi 16 For Windows.

Hasil penelitian menunjukkan bahwa Kualitas Layanan Fisik (tangible), Layanan Kehandalan (reability), Layanan Ketanggapan (Responsive), layanan jaminan (assurance) dan Layanan Empati (empathy) tidak berpengaruh dan tidak signifikan terhadap Prestasi Belajar, hanya Layanan Kehandalan (reability) berpengaruh dan signifikan terhadap Prestasi Belajar. Hasil penelitian menunjukkan bahwa layanan fisik (tangible), layanan kehandalan (reability), Layanan Ketanggapan (Responsive), layanan jaminan (assurance) dan Layanan Empati (empathy) tidak berpengaruh dan tidak signifikan terhadap Kepuasan Mahasiswa hanya Layanan informasi system yang berpengaruh dan signifikan terhadap Kepuasan Mahasiswa. Hasil penelitian menunjukkan bahwa Prestasi Belajar berpengaruh dan signifikan terhadap Kepuasan Mahaiswa. Prestasi Belajar Tidak Memediasi Pengaruh Kualitas Layanan layanan fisik (tangible), Layanan Ketanggapan (Responsive), layanan jaminan (assurance), Layanan Empati (empathy) dan informasi syst.em Pada Kepuasan Mahasiswa, Prestasi Belajar Memediasi Pengaruh Kualitas Layanan Kehandalan (reability) Pada Kepuasan Mahasiswa.
\end{abstract}

Kata Kunci: Layanan, Prestasi Belajar, Kepuasan Mahasiswa.

\begin{abstract}
The purpose of this study is to Analyze the Mediation of Learning Achievements in the Effect of Service Quality on Student Satisfaction (Study of Malang Islamic University Students). Where Service Quality as variable X consists of six variables, namely physical services, reliability, responsiveness, assurance, empathy and information systems. The population in this study were all UNISMA students. So this research is quantitative research, which uses survey methods by taking samples from a population and using questionnaires or questionnaires as the main data collection tool, with a total of 175 respondents. The data analysis technique in this study used the Instrument Test, Normality Test, Data Analysis, Test of Hypothesis T and Sobel. SPSS version 16 For Windows software program.
\end{abstract}


The results showed that the quality of physical services, service reliability, service responsiveness, assurance services and services Empathy had no effect and were not significant towards Learning Achievement, only the service Reliability influential and significant to Learning Achievement. The results showed that tangible services, reliability services, responsiveness services, assurance services and Empathy services did not influence and were not significant towards Student Satisfaction, only information system services that had an effect on and significantly affected Student Satisfaction. The results of the study showed that Learning Achievement had significant and significant effect on Student Satisfaction. Learning Achievement Does Not Mediate the Effect of Physical Service Quality, Responsiveness, Assurance services, Empathy Service and information system on Student Satisfaction, Learning Achievement Mediates the Effect of Service Quality Reliability on Student Satisfaction.

Keywords: Services, Learning Achievement, Student Satisfaction.

\section{PENDAHULUAN}

Kepuasan konsumen penting untuk mempertahankan pelanggan, menurut Griffin (2010:12), enam alasan pentingnya mempertahankan pelanggan yang pertama, mengurangi biaya pemasaran, karena biaya untuk menarik konsumen lebih mahal. Kedua, mengurangi biaya transaksi, seperti biaya negosiasi kontrak, pemrosesan, dan pemasaran. Ketiga, mengurangi biaya turn over konsumen. Keempat, meningkatkan penjualan silang yang akan memperbesar pangsa pasar. Kelima, word of mouth yang lebih lebih besar dengan asumsi bahwa pelanggan yang loyal juga berarti pelanggan yang puas. Keenam, mengurangi biaya kegagalan, seperti biaya penggantian.

Konsumen dalam hal ini adalah Mahasiswa. dapat dikatakan bagi Perguruan Tinggi yang mempunyai kareteristik relatif kompleks dan beragam, sehingga pelanggan tidak hanya tunggal (single) tetapi banyak pihak (multiple) dengan faktor atau kriteria kepuasan berbeda-beda (Amin, 2017). Mahasiswa adalah stakeholder inti karena pihak yang berkepentingan dan langsung dipengaruhi oleh pembelajaran dan manajemen pengelola perguruan tinggi (Amin, 2017). Perguruan tinggi merupakan salah satu lembaga penyedia jasa yang tidak akan terlepas dari pelayanan yang diberikan kepada mahasiswa selaku konsumen (Rudini, 2015).

Dalam penelitian Kriswandari (2011) menyatakan ada empat faktor yang mempengaruhi kepuasan konsumen yaitu, Kualitas Pelayanan Kualitas Dosen, Kualitas Fasilitas, Biaya Pendidikan.

Dalam penelitian (Lily Suhaily, 2015) disebutkan bahwa faktor-faktor yang berdampak positif dalam prestasi belajar meliputi banyak hal, diantaranya adalah, sikap dosen terhadap mahasiswa, jenis control kelas, kurikulum, kecukupan dosen dalam kualifikasi dan persiapan professional, isi dan presentasi pengajaran, penggunaan alat peraga yang relevan (Bunga, 1966; Burstall, 1970; Pidgeon, 1970). Disebutkan juga pengaruh positif prestasi belajar adalah kemampuan dosen dalam memberikan penjelasan materi yang diberikan, kualifikasi dosen dalam penguasaan sains. Sedangkan kondisi bngunan kampus seperti kondsi lift dan ruang kelas mempengaruhi pula pada prestasi belajar mahasiswa (Edward, 
1991), ruang kelas yang nyaman, serta ruangan yang ber AC mempengaruhi pencapaian mahasiswa (Angrist \& Lavy, 1999; Hoxby, 2000)

Berdasarkan latar belakang serta dari hasil pengamatan yang kemudian dijabarkan di atas maka peneliti melakukan penjajakan di lapangan, dengan tujuan Untuk menganalisis Pengaruh Mediasi Prestasi Belajar pada Kualitas Layanan Fisik (tangible), Layanan Kehandalan (reability), Layanan Ketanggapan (Responsive), Layanan jaminan (Assurance), Layanan Empati (Empathy) dan Layanan Sistem Infomasi terhadap Kepuasan Mahasiswa.

\section{KAJIAN TEORI}

\section{Pengertian Kualitas Layanan}

Menurut Tjiptono (2007:73) bahwa "kualitas layanan adalah upaya pemenuhan dan keingingan konsumen serta ketetapan penyampaiannya dalam mengimbangi harapan konsumen".

Menurut Parasuraman (1998) dalam Kaihatsu (2008:69) mengungkapkan bahwa kualitas pelayanan merupakan dasar bagi pemasaran jasa, karena ini produk yang dipasarkan adalah suatu kinerja (yang berkualitas) dan kinerjalah yang dibeli oleh pelanggan, oleh karena itu kualitas kinerja pelayanan merupakan dasar bagi pemasaran jasa.

Menurut Berry dan Zenthaml dalam Lupiyoadi (2010:181) berpendapat bahwa "Keberhasilan perusahaan dalam memberikan pelayanan yang berkualitas dapat ditentukan dengan pendapat Service Quality yang telah dikembangkan oleh peusahaan".

\section{Prestasi Belajar}

Prestasi belajar merupakan gabungan dari dua kata, yaitu prestasi dan belajar, yang mana pada setiap kata tersebut memiliki makna tersendiri. Dalam kamus besar bahasa Indonesia, prestasi adalah hasil yang telah dicapai (dari yang telah dilakukan, dikerjakan, dan sebagainya). Prestasi dapat diartikan sebagai hasil yang diperoleh karena adanya aktivitas belajar yang telah dilakukan Fathurrahman (2012:118).

Kata prestasi berasal dari bahasa Belanda yaitu prestatie. Kemudian dalam bahasa Indonesia menjadi prestasi yang berarti hasil usaha. Istilah prestasi belajar (achievement) berbeda dengan hasil belajar (learning outcome). Prestasi belajar pada umumnya berkenaan dengan aspek pengetahuan sedangkan hasil belajar meliputi aspek pembentukan watak peserta didik (Arifin, 2009:12).

Belajar ialah suatu proses usaha yang dilakukan seseorang untuk memperoleh suatu perubahan tingkah laku yang baru secara keseluruhan, sebagai hasil pengalamannya sendiri dalam interaksi dengan lingkungannya (Slameto, 2010:2).

\section{Kepuasan Mahasiswa}

Menurut Kotler dalam Tjiptono (2019: 24), bahwa: Kepuasan Pelanggan adalah tingkat perasaan seseorang setelah membandingkan kinerja (atau hasil) yang ia rasakan, dibandingkan dengan harapannya. 
Sedangkan menurut Bitner dan Zeithaml (2003:86), "kepuasan pelanggan adalah evaluasi pelanggan terhadap produk atau jasa yang diterima apakah sesuai dengan kebutuhan dan harapan pelanggan". Dari beberapa pengertian di atas dapat disimpulkan bahwa kepuasan konsumen atau mahasiswa merupakan suatu tingkat perasaan konsumen atau pelanggan tentang kinerja yang ia rasakan terhadap kebutuhan, keinginan, dan harapannya yang kemudian akan berdampak pada keputusan kepuasan mahasiswa itu sendiri.

\section{Populasi dan sampel}

Populasi adalah keseluruhan dari subjek penelitian. Jadi yang dimaksud populasi adalah individu yang memiliki sifat yang sama walaupun prosentase kesamaan itu sedikit, atau dengan kata lain seluruh individu yang akan dijadikan sebagai obyek penelitian Arikunto, (2013:173). Populasi dalam penelitian ini adalah seluruh Mahasiswa Universitas Islam Malang Tahun Akademik 2018-2019, dengan jumlah 14.382 Mahasiswa.

Sampel adalah sebagian atau wakil populasi yang diteliti Arikunto, (2013:173). Dengan jumlah 175 Mahasiswa.

\section{Definisi Oprasional Variabel}

Variabel Bebas (Independent) Variabel bebas menurut Sugiyono (2017:39) adalah "variabel yang mempengaruhi atau yang menjadi sebab perubahannya atau timbulnya variabel terikat (dependent)". Varibel Bebas dalam penelitian ini adalah Kualitas Layanan $(X)$ yang meliputi Layanan Fisik (Tangible), kehandalan (Realibily), Daya Tanggap (Responsive), Jaminan (Assurance), Empati atau Perhatian (Empathy) dan Informasi sistem.

Variabel Terikat (Dependent) Varibel terikat menurut Sugiyono (2017: 39) adalah "varibel yang dipengaruhi atau menjadi akibat karena adanya variabel bebas". Variabel Terikat dalam penelitian ini adalah Kepuasan Mahasiswa (Y).

\section{Uji Instrumen}

Agar data yang diperoleh mempunyai tingkat akurasi dan konsistensi yang tinggi, instrument penelitian yng digunakan harus valid dan reabel (Sanusi, 2014: 76).

Uji Validitas Untuk mengukur valid atau tidaknya suatu kuesioner digunakan uji validitas. Uji validitas mengukur apakah pertanyaan dalam kuesioner yang digunakan betul-betul dapat mengukur apa yang hendak diukur. Pengujian validitas selain untuk mengetahui dan mengungkapkan data dengan tepat juga harus memberikan gambaran yang cermat mengenai data tersebut Teknik yang digunakan untuk mengukur validitas dalam penelitian ini adalah dengan menggunakan Pearson's Correlation yaitu dengan cara menghitung korelasi antara nilai yang diperoleh dari pertanyaan-pertanyaan. Suatu pertanyaan dikatakan valid jika tingkat signifikansinya berada di bawah 0,05. (Ghozali, 2012: 52). Uji Reliabilitas Untuk mengukur suatu kuesioner yang merupakan indikator dari variabel atau konstruk digunakan uji reliabilitas. Suatu kuesioner dikatakan reliabel 
atau handal jika jawaban seseorang terhadap pernyataan adalah konsisten atau stabil dari waktu ke waktu. Reliabilitas mencakup 3 (tiga) hal utama yaitu stabilitas ukuran, ekuivalen dan konsistensi internal ukuran. Uji reliabilitas dalam penelitian ini dilakukan dengan uji statistic Cronbach Alpha $(\alpha)$. Suatu konstruk atau variabel dikatakan reliabel jika memberikan nilai Cronbach Alpha > 0,60 (Ghozali, 2012:47).

\section{Uji Normalitas}

Uji Normalitas bertujuan untuk menguji apakah dalam model regresi, variabel pengganggu atau residual memiliki distribusi normal. Contohnya jika diketahui, uji $t$ dan $F$ mengasumsikan bahwa nilai residual mengikuti distribusi normal. Kalau asumsi ini dilanggar maka uji statistik menjadi tidak valid untuk jumlah sampel kecil. Cara untuk mendeteksi apakah residual berdistribusi normal atau tidak yaitu dengan analisis grafik atau uji statistik dengan tes one sample kolmogrov-smirnov (Ghozali, 2016: 154).

a. Jika nilai Asym. Sig. (2 tailed) kurang dari 0,05, maka $\mathrm{H}_{0}$ akan ditolak. Hal ini berarti data residul terdistribusi tidak normal.

b. Jika nilai Asym. Sig. (2 tailed) lebih dari 0,05, maka $\mathrm{H}_{0}$ diterima. Hal ini berarti residul terdistribusi normal.

\section{Analisis Data}

Dalam penelitian ini menggunakan metode analisis jalur (Analysis Path) Alrassyid dalam Sanusi (2011:156) mendefinisikan "Analysis Path (jalur) bertujuan untuk menerangkan akibat langsung dan tidak langsung seperangkat variabel bebas dengan seperangkat variabel terikat".

\section{Uji Hipotesis} sobel.

Pengujian Hipotesis dalam penelitian ini menggunakan uji t dan uji

\section{a. Uji t (t-test)}

Pengujian ini bertujuan untuk mengetahui apakah setiap variable bebas berpengaruh secara signifikan terhadap variable terikat pada tingkat derajat keyakinan tertentu. $\mathrm{H}_{0}$ diterima, bila t-tabel > t-hitung, berarti tidak ada pengaruh yang signifikan dari variable bebas terhadap variable terikat. $\mathrm{H}_{\mathrm{a}}$ diterima, bila $\mathrm{t}$ hitung > t-tabel berarti ada pengaruh yang signifikan dari variabel bebas terhadap variabel terikat (Aisyah 2015:71).

\section{b. Uji Sobel atau Uji Mediasi}

Uji mediasi dapat dilakukan dengan prosedur yang dikembangkan oleh Sobel dan dikenal dengan uji sobel (Ghazali, 2016:237). Uji sobel dilakukan dengan cara mengujih kekuatan pengaruh tidak langsung variabel $(X)$ kepada variabel endogen $(Y)$ melalui intervening $(Z)$. pengaruh tidak langsung $X$ ke $Y$ melalui $Z$ dihitung dengan cara mengkalikan jalur $X$ ke $Z$ (a) dengan jalur $Z$ ke $Y(b)$ atau ab. Jadi koefisien $a b=(c-c ")$, dimana $c$ adalah pengaruh $X$ terhadap $Y$ tanpa mengontrol $Z$, sedangkan c" adalah Koefisien Pengaruh $X$ ke $Y$ setelah mengontol Z. Standar eror koefisien a dan b ditulis dengan $\mathrm{Sa}$ 
dan $\mathrm{Sb}$, besarnya standar eror tidak langsung (Indirect effect) Sab dihitung dengan rumus berikut ini :

$$
S a b=\sqrt{b^{2} S a^{2}+a^{2} S b^{2}+S a^{2} S b^{2}}
$$

Untuk mengujih signifikansi pengaruh tidak langsung maka kita perlu menghitung nilai $t$ dari koefisien ab dengan rumus sebagai berikut: $\mathrm{t}=\frac{a b}{S a b}$

Nilai t hitung ini dibandingkan dengan nilai $t$ table dan jika nilai t hitung lebih besar dari nilai $t$ table maka dapat disimpulkan bahwa terjadi pengaruh mediasi. Terdapat dua jenis pengaruh mediasi yakni mediasi penuh (Full Mediation) dan mediasi sebagian (Partial Mediation), dimana full mediation ini menunjukan bahwa variable eksogen sepenuhnya dimediasi oleh mediator karena tidak ada lagi pengaruh langsung dari variable eksogen terhadap variable endogen. Sementara partial mediation menunjukan bahwa disamping memiliki pengaruh tidak langsung melalui mediator, variabel eksogen juga mempunyai pengaruh langsung yang signifikan pada variable endogen.

Semua perhitungan dan analisis data dilakukan dengan menggunakan Software Program SPSS versi 16 For Windows.

\section{HASIL ANALISIS DATA}

Berdasarkan hasil Berdasarkan Tabel 4.14 diatas terlihat bahwa nilai signifikansi residual regresi yang terbentuk lebih besar dari taraf nyata $5 \%$ sehingga dapat dikatakan bahwa asumsi normalitas tersebut terpenuhi.

Tabel 4.14

Hasil Uji Normalitas Kolmogorov Smirnov

\begin{tabular}{|l|l|l|l|}
\hline Variabel & $\begin{array}{l}\text { Kolmogorof } \\
\text { Smirnov Z }\end{array}$ & $\begin{array}{l}\text { Nilai } \\
\text { Sig. }\end{array}$ & Keterangan \\
\hline X1 Layanan Fisik (tangible) & 0,707 & 0,699 & Berdistribusi Normal \\
\hline X2 Kehandalan (reability) & 0,890 & 0,407 & Berdistribusi Normal \\
\hline X3 Ketanggapan (responsive) & 1,523 & 0,431 & Berdistribusi Normal \\
\hline X4 Jaminan (assurance) & 0,873 & 0,431 & Berdistribusi Normal \\
\hline X5 Empati (empathy) & 1,115 & 0,166 & Berdistribusi Normal \\
\hline X6 Informasi Sistem & 1,117 & 0,164 & Berdistribusi Normal \\
\hline Z Prestasi Belajar & 1,057 & 0,214 & Berdistribusi Normal \\
\hline Y Kepuasan Mahasiswa & 0,716 & 0,685 & Berdistribusi Normal \\
\hline
\end{tabular}

Sumber : Data diolah, 2019 


\section{Analisis Data}

\section{a. Model path 1}

Tabel 4.15

Hasil regresi linier berganda

Coefficients $^{\mathrm{a}}$

\begin{tabular}{|c|c|c|c|c|c|c|}
\hline \multirow{2}{*}{\multicolumn{2}{|c|}{ Model }} & \multicolumn{2}{|c|}{ Unstandardized Coefficients } & \multirow{2}{*}{$\begin{array}{c}\begin{array}{c}\text { Standardized } \\
\text { Coefficients }\end{array} \\
\text { Beta } \\
\end{array}$} & \multirow[b]{2}{*}{$\mathrm{t}$} & \multirow[b]{2}{*}{ Sig. } \\
\hline & & B & Std. Error & & & \\
\hline \multirow[t]{7}{*}{1} & (Constant) & 16.280 & 1.995 & & 8.161 & .000 \\
\hline & Tangible & .039 & .052 & .070 & .741 & .460 \\
\hline & Reability & .295 & .101 & .326 & 2.914 & .004 \\
\hline & Responsive & .084 & .202 & .043 & .414 & .679 \\
\hline & Assurance & .087 & .127 & .085 & .690 & .491 \\
\hline & Empathy & -.020 & .168 & -.013 & -.118 & .906 \\
\hline & Sistem Informasi & .147 & .124 & .120 & 1.184 & .238 \\
\hline
\end{tabular}

a. Dependent Variable: Prestasi Belajar

Sumber : Data Sudah diolah,2019.

Persamaan regresi model satu pada tabel 4.15 adalah sebagai berikut:

$Z=0,070 X_{1}+0,326 X_{2}+0,040 X_{3}+0,085 X_{4}+-0,013 X_{5}+$ $0,120 X_{6}$ Hasil persamaan regresi:

1) $\beta_{1}$ (nilai koefisien regresi $X_{1}$ ) 0,070 mempunyai arti bahwa tangible (layanan fisik) berpengaruh positif terhadap prestasi belajar mahaiswa. Jika semakin baik kulitas layana fisik yang diberikan, maka prestasi belajar mahasiswa semakin meningkat.

2) $\beta_{2}$ (nilai koefisien regresi $X_{2}$ ) 0,326 mempunyai arti bahwa reability (layanan kehandalan) berpengaruh positif terhadap prestasi belajar mahaiswa. Jika semakin baik layanan kehandalan yang diberikan, maka prestasi belajar mahasiswa semakin meningkat.

3) $\beta_{3}$ (nilai koefisien regresi $X_{3}$ ) 0,040 mempunyai arti bahwa responsive (layanan ketanggapan) berpengaruh positif terhadap prestasi belajar mahaiswa. Jika semakin baik layanan ketanggapan yang diberikan, maka prestasi belajar mahasiswa semakin meningkat.

4) $\beta_{4}$ (nilai koefisien regresi $X_{4}$ ) 0,085 mempunyai arti bahwa assurance (layanan jaminan) berpengaruh positif terhadap prestasi belajar mahaiswa. Jika semakin baik layanan jaminan yang diberikan, maka prestasi belajar mahasiswa semakin meningkat.

5) $\beta_{5}$ (nilai koefisien regresi $X_{5}$ ) $-0,013$ mempunyai arti bahwa empathy (layanan empati) berpengaruh negative terhadap prestasi belajar mahaiswa. 
6) $\beta_{6}$ (nilai koefisien regresi $X_{6}$ ) 0,120 mempunyai arti bahwa layanan informasi system berpengaruh positif terhadap prestasi belajar mahaiswa. Jika semakin baik layanan informasi system yang diberikan, maka prestasi belajar mahasiswa semakin meningkat.

\section{b. Model path 2}

Tabel 4.16

Hasil regresi linier berganda

Coefficients $^{a}$

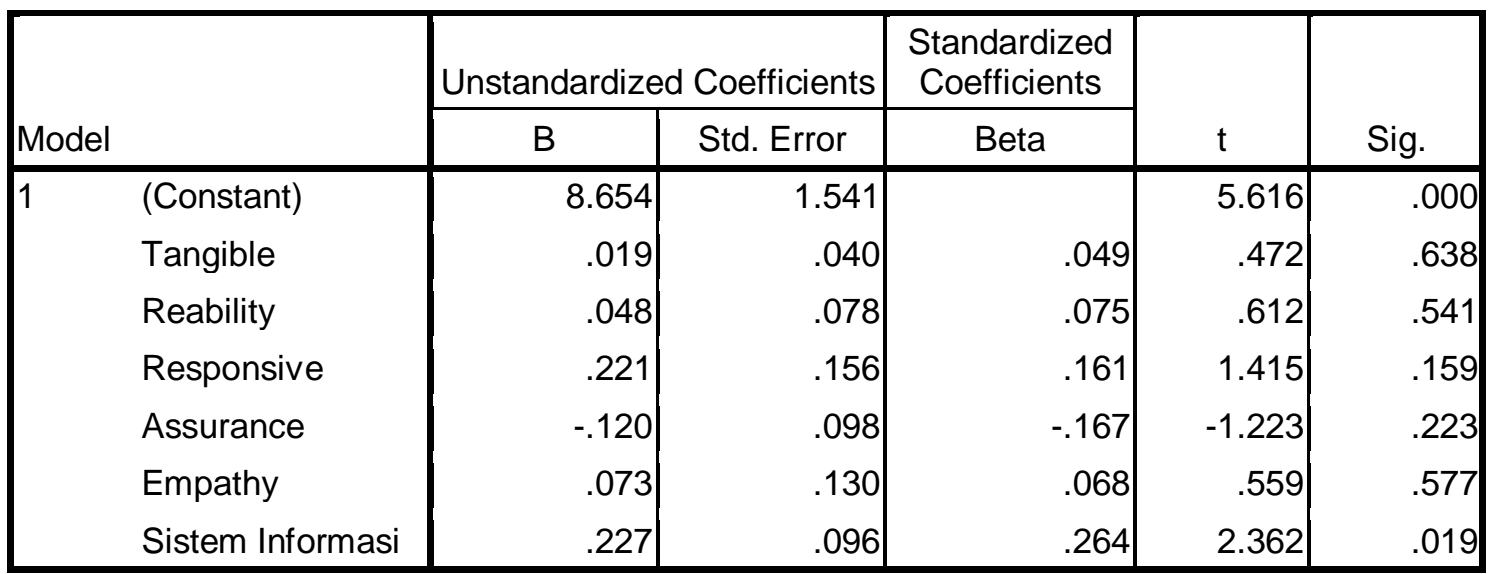

a. Dependent Variable: Kepuasan Mahasiswa

Sumber : Data Sudah diolah,2019.

Persamaan regresi model satu pada tabel 4.16 adalah sebagai berikut:

$Y=0,049 X_{1}+0,075 X_{2}+0,161 X_{3}+-0,167 X_{4}+0,068$ $X_{5}+0,264 X_{6}$ Hasil persamaan regresi:

1) $\beta_{1}$ (nilai koefisien regresi $X_{1}$ ) 0,049 mempunyai arti bahwa tangible (layanan fisik) berpengaruh positif terhadap kepuasan mahaiswa. Jika semakin baik kulitas layanan fisik yang diberikan, maka kepuasan mahasiswa semakin meningkat.

2) $\beta_{2}$ (nilai koefisien regresi $X_{2}$ ) 0,075 mempunyai arti bahwa reability (layanan kehandalan) berpengaruh positif terhadap kepuasan mahaiswa. Jika semakin baik layanan kehandalan yang diberikan, maka kepuasan mahasiswa semakin meningkat.

3) $\beta_{3}$ (nilai koefisien regresi $X_{3}$ ) 0,161 mempunyai arti bahwa responsive (layanan ketanggapan) berpengaruh positif terhadap kepuasan mahaiswa. Jika semakin baik layanan ketanggapan yang 
diberikan, maka kepuasan mahasiswa semakin meningkat.

4) $\beta_{4}$ (nilai koefisien regresi $X_{4}$ ) $-0,167$ mempunyai arti bahwa assurance (layanan jaminan) berpengaruh negatif terhadap kepuasan mahaiswa. Jika semakin baik layanan jaminan yang diberikan, maka kepuasan mahasiswa semakin meningkat.

5) $\beta_{5}$ (nilai koefisien regresi $X_{5}$ ) 0,068 mempunyai arti bahwa empathy (layanan empati) berpengaruh negative terhadap prestasi belajar mahaiswa.

6) $\beta_{6}$ (nilai koefisien regresi $X_{6}$ ) 0,264 mempunyai arti bahwa layanan informasi system mempunyai arti bahwa empathy (layanan empati) berpengaruh positif terhadap kepuasan mahaiswa. Jika semakin baik layanan jaminan yang diberikan, maka kepuasan mahasiswa semakin meningkat.

\section{b. Model path 3}

Tabel 4.17

Hasil regresi linier berganda

Coefficients(a)

\begin{tabular}{|l|l|r|r|r|r|r|}
\hline & & \multicolumn{2}{|c|}{$\begin{array}{c}\text { Unstandardized } \\
\text { Coefficients }\end{array}$} & $\begin{array}{c}\text { Standardized } \\
\text { Coefficients }\end{array}$ & & \\
\cline { 3 - 5 } Model & & \multicolumn{1}{|c|}{ B } & Std. Error & \multicolumn{1}{c|}{ Beta } & \multicolumn{1}{c|}{ t } & \multicolumn{1}{c|}{ Sig. } \\
\hline 1 & (Constant) & 1.582 & .379 & & 4.179 & .000 \\
& Z & .619 & .096 & .442 & 6.483 & .000 \\
\hline
\end{tabular}

a. dependen variabel: kepuasan mahasiswa

Sumber : Data Sudah diolah,2019.

Persamaan regresi model satu pada tabel 4.17 adalah sebagai berikut:

$Y=0,442 \mathrm{Z}$ Hasil persamaan regresi:

$\beta_{1}$ (nilai koefisien regresi Z) 0,442 mempunyai arti bahwa Prestasi Belajar berpengaruh positif terhadap Kepuasan Mahaiswa. Jika Prestasi Belajar semakin baik, maka mahasiswa sangat puas.

\section{Uji Hipotesis}

\section{a. Pengujian Signifikansi Simultan (uji t)}

Pengujian signifikansi simultan digunakan untuk mengujih hipotesis mengenai ada tidaknya pengaruh variabel eksogen secara simultan (bersama-sama) terhadap variabel endogen. Kriteria pengujian menyatakan bahwa apabila nilai probabilitas $<$ level of significant (alpha $=\alpha$ ) maka dinyatakan adanya pengaruh variabel eksogen secara simultan terhadap variabel 
endogen. Pengujian signifikansi simultan dapat diketahui melalui ringkasan pada table berikut ini.

Tabel 4.18

Tabel Signifikan Simultan

\begin{tabular}{|c|c|c|c|c|}
\hline \multicolumn{2}{|c|}{ Standerdized } & \multirow{2}{*}{$\begin{array}{c}T \text { hitung } \\
\text { t tabel }\end{array}$} & \multirow{2}{*}{$\operatorname{Sig} \alpha$} & \multirow{2}{*}{ Keterangan } \\
\hline Jalur & $\overline{B e t a}(\beta)$ & & & \\
\hline $\mathrm{X} 1-\mathrm{Y}$ & 0,049 & $0,472<1,653$ & $0,638>0,05$ & Tidak Signifikan \\
\hline$X 2-Y$ & 0,075 & $0,612<1,653$ & $0,541>0,05$ & Tidak Signifikan \\
\hline X3-Y & 0,161 & $1,415<1,653$ & $0,159>0,05$ & Tidak Signifikan \\
\hline$X 4-Y$ & $-0,167$ & $-1,223<1,653$ & $0,223>0,05$ & Tidak Signifikan \\
\hline$X 5-Y$ & $0,, 068$ & $0,559<1,653$ & $0,577>0,05$ & Tidak Signifikan \\
\hline$X 6-Y$ & 0,264 & $2,362>1,653$ & $0,019<0,05$ & Signifikan \\
\hline $\mathrm{X} 1-\mathrm{Z}$ & 0,070 & $0,741<1,653$ & $0,460>0,05$ & Tidak Signifikan \\
\hline$X 2-Z$ & 0,326 & $2,914>1,653$ & $0,004<0,05$ & Signifikan \\
\hline X3-Z & 0,043 & $0,414<1,653$ & $0,679>0,05$ & Tidak Signifikan \\
\hline$X 4-Z$ & 0,085 & $0,690<1,653$ & $0,491>0,05$ & Tidak Signifikan \\
\hline$X 5-Z$ & $-0,013$ & $-0,118<1,653$ & $0,906>0,05$ & Tidak Signifikan \\
\hline X6-Z & 0,120 & $1,184<1,653$ & $0,238>0,05$ & Tidak Signifikan \\
\hline Z-Y & 0,442 & $6,483>1,653$ & $0,000<0,05$ & Signifikan \\
\hline $\mathrm{e} 1$ & 0,7199 & - & - & - \\
\hline $\mathrm{e} 2$ & 0,69681 & - & - & - \\
\hline
\end{tabular}

Sumber : Data Sudah diolah,2019.

Berdasarkan Tabel 4.18 diatas, maka dapat dibentuk persamaan model empiric berdasarkan hasil koefisien jalur sebagai berikut:

1) Persamaan Model I:

$Y=0,049 X_{1}+0,075 X_{2}+0,161 X_{3}+-0,167 X_{4}+0,068 X_{5}$ $+0,264 X_{6}$

Tangible $+0,049$ reability $+0,075$ responsive $-0,161$ assurance $+0,167$ empathy $+0,068$ informasi system $+0,264$

2) Persamaan Model II :

$Z=0,070 X_{1}+0,326 X_{2}+0,040 X_{3}+0,085 X_{4}+-0,013$ $X_{5}+0,120 X_{6}$

Tangible 0,070 reability $+0,326$ responsive $+0,040$ assurance $+0,085$ empathy $-0,013$ informasi system $+0,120$ 


\section{b. Pengujian Signifikan Parsial (Uji t)}

Pengujian signifikansi parsial digunakan untuk mengujih hipotesis mengenai ada tidaknya pengaruh variabel eksogen secara parsial terhadap variabel endogen. Kriteria pengujian menyatakan bahwa apabila nilai probabilitas < level of significant (alpha $=\alpha$ ) maka dinyatakan adanya pengaruh variabel eksogen secara parsial terhadap variabel endogen. Pengujian signifikansi dapat diketahui melalui ringkasan pada table berikut ini.

Tabel 4.19

Tabel Persamaan Struktural dan Besar Pengaruh

\begin{tabular}{|c|c|c|c|c|c|}
\hline Eksogen & Endogen & Koefisiensi & t statistic & Sig. & Keterangan \\
\hline $\begin{array}{l}\text { X1 Layanan Fisik } \\
\text { (tangible) }\end{array}$ & $\begin{array}{c}\text { Kepuasan } \\
\text { Mahasiswa } \\
(Y)\end{array}$ & 0,019 & 1.108 & 0,638 & $\begin{array}{c}\text { Tidak } \\
\text { Berpengaruh }\end{array}$ \\
\hline $\begin{array}{l}\text { X2 Kehandalan } \\
\text { (reability) }\end{array}$ & $\begin{array}{c}\text { Kepuasan } \\
\text { Mahasiswa } \\
(Y)\end{array}$ & 0,048 & .549 & 0,541 & $\begin{array}{c}\text { Tidak } \\
\text { Berpengaruh }\end{array}$ \\
\hline $\begin{array}{l}\text { X3 Ketanggapan } \\
\text { (responsive) }\end{array}$ & $\begin{array}{c}\text { Kepuasan } \\
\text { Mahasiswa } \\
(Y)\end{array}$ & 0,221 & 1.328 & 0,159 & $\begin{array}{c}\text { Tidak } \\
\text { Berpengaruh }\end{array}$ \\
\hline $\begin{array}{l}\text { X4 Jaminan } \\
\text { (assurance) }\end{array}$ & $\begin{array}{c}\text { Kepuasan } \\
\text { Mahasiswa } \\
(Y)\end{array}$ & $-0,120$ & -1.291 & 0,223 & $\begin{array}{c}\text { Tidak } \\
\text { Berpengaruh }\end{array}$ \\
\hline $\begin{array}{l}\text { X5 Empati } \\
\text { (empathy) }\end{array}$ & $\begin{array}{c}\text { Kepuasan } \\
\text { Mahasiswa } \\
(Y)\end{array}$ & 0,073 & .439 & 0,577 & $\begin{array}{c}\text { Tidak } \\
\text { Berpengaruh }\end{array}$ \\
\hline $\begin{array}{l}\text { X6 Informasi } \\
\text { Sistem }\end{array}$ & $\begin{array}{c}\text { Kepuasan } \\
\text { Mahasiswa } \\
(Y)\end{array}$ & 0,227 & 2.158 & 0,019 & Pengaruh \\
\hline $\begin{array}{l}\text { X1 Layanan Fisik } \\
\text { (tangible) }\end{array}$ & $\begin{array}{c}\text { Prestasi } \\
\text { Belajar (Z) }\end{array}$ & 0,039 & .891 & .374 & $\begin{array}{c}\text { Tidak } \\
\text { Berpengaruh }\end{array}$ \\
\hline $\begin{array}{l}\text { X2 Kehandalan } \\
\text { (reability) }\end{array}$ & $\begin{array}{l}\text { Prestasi } \\
\text { Belajar (Z) }\end{array}$ & 0,295 & 2.975 & .003 & Pengaruh \\
\hline $\begin{array}{l}\text { X3 Ketanggapan } \\
\text { (responsive) }\end{array}$ & $\begin{array}{l}\text { Prestasi } \\
\text { Belajar (Z) }\end{array}$ & 0,084 & .360 & .720 & $\begin{array}{c}\text { Tidak } \\
\text { Berpengaruh }\end{array}$ \\
\hline $\begin{array}{l}\text { X4 Jaminan } \\
\text { (assurance) }\end{array}$ & $\begin{array}{c}\text { Prestasi } \\
\text { Belajar (Z) }\end{array}$ & 0,087 & .739 & .461 & $\begin{array}{c}\text { Tidak } \\
\text { Berpengaruh }\end{array}$ \\
\hline $\begin{array}{l}\text { X5 Empati } \\
\text { (empathy) }\end{array}$ & $\begin{array}{l}\text { Prestasi } \\
\text { Belajar (Z) }\end{array}$ & $-0,020$ & -.177 & .860 & $\begin{array}{c}\text { Tidak } \\
\text { Berpengaruh }\end{array}$ \\
\hline $\begin{array}{l}\text { X6 Informasi } \\
\text { Sistem }\end{array}$ & $\begin{array}{c}\text { Prestasi } \\
\text { Belajar (Z) }\end{array}$ & 0,147 & 1.070 & .286 & $\begin{array}{c}\text { Tidak } \\
\text { Berpengaruh }\end{array}$ \\
\hline Prestasi Belajar (Z) & $\begin{array}{c}\text { Kepuasan } \\
\text { Mahasiswa } \\
(Y)\end{array}$ & 0,619 & 6.483 & .000 & Pengaruh \\
\hline
\end{tabular}

Sumber : Data diolah, 2019. 


\subsubsection{Uji Sobel}

Uji Sobel merupakan uji untuk mengetahui apakah hubungan yang melalui sebuah variabel mediasi secara signifikan mampu sebagai mediator dalam hubungan tersebut. Untuk menghitung nilai Z dari Sobel test dapat dilakukan dengan cara Online Kalkulator di, www.danielsoper.com yaitu sebagai berikut:

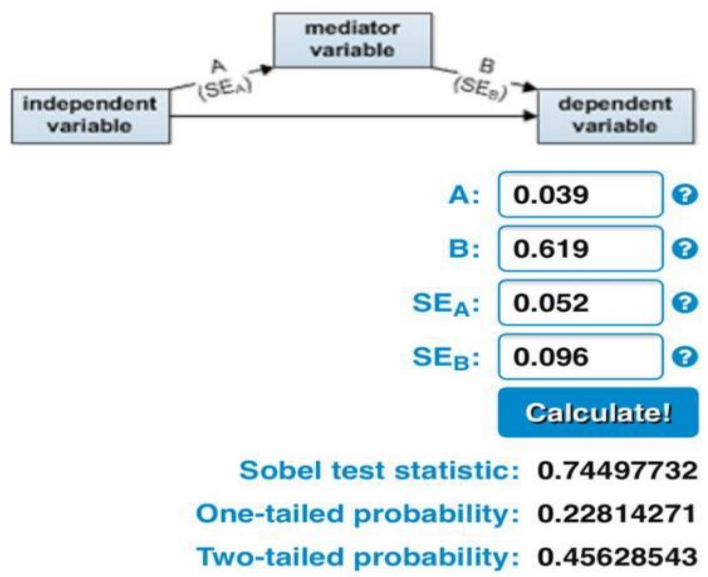

\section{Gambar 4.1 Uji Sobel Test Model 1}

Berdasarkan gambar 4.1 di atas menunjukkan hasil onetailled probality sebesar 0,22814271 > 0,05, sehingga dapat disimpulkan variabel Prestasi Belajar (Z) tidak memediasi variabel Layanan Fisik (Tangble) $\mathrm{X} 1$ terhadap Kepuasan Mahasiswa (Y).

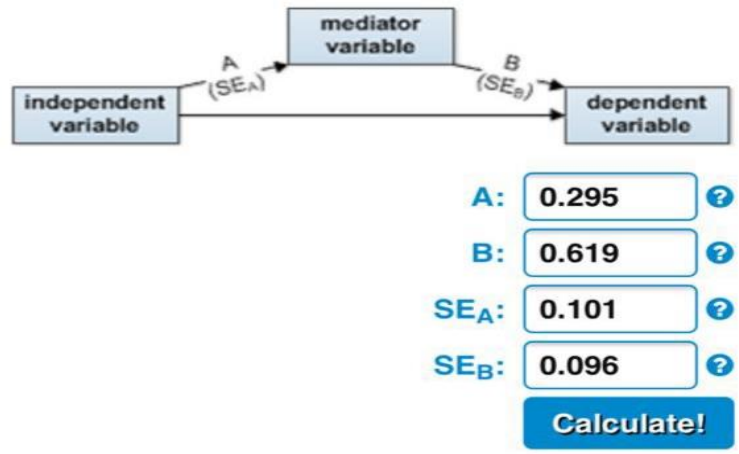

Sobel test statistic: $\mathbf{2 . 6 6 0 5 5 5 6 6}$ One-tailed probability: $\mathbf{0 . 0 0 3 9 0 0 5 9}$ Two-tailed probability: $\mathbf{0 . 0 0 7 8 0 1 1 8}$

Gambar 4.2

Uji Sobel Test Model 2

Berdasarkan gambar 4.2 di atas menunjukkan hasil onetailled probality sebesar 0,00390059 $<0,05$, sehingga dapat 
disimpulkan variabel Prestasi Belajar (Z) memediasi variebel Layanan kehandalan (Reablity) X2 terhadap Kepuasan Mahasiswa (Y).

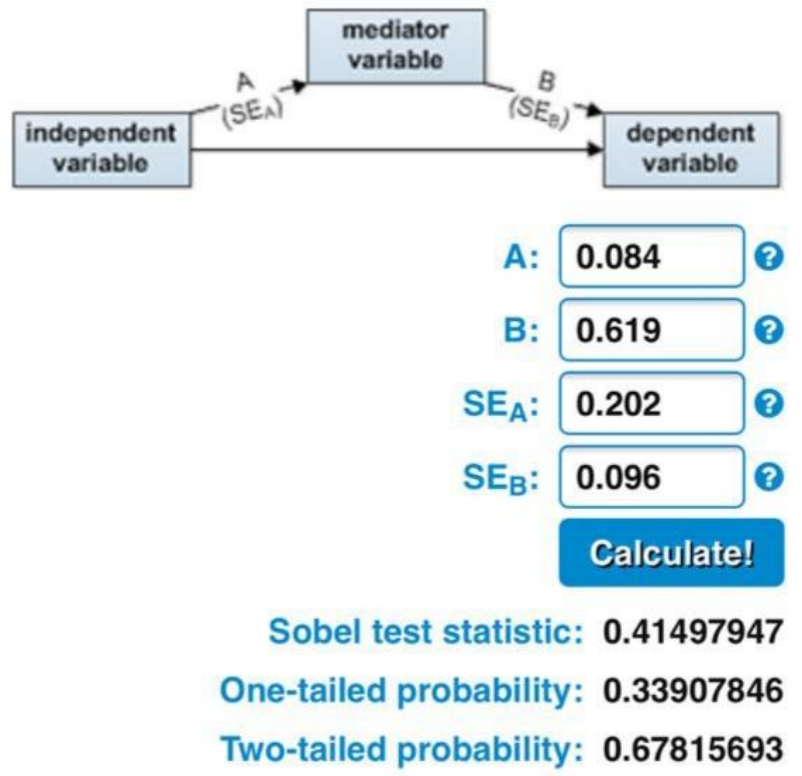

\section{Gambar 4.3 \\ Uji Sobel Test Model 3}

Berdasarkan gambar 4.3 di atas menunjukkan hasil onetailled probality sebesar 0,33907846 >0,05, sehingga dapat disimpulkan variabel Prestasi Belajar ( $Z$ ) tidak memediasi variebel Layanan ketanggapan (Responsive) X3 terhadap Kepuasan Mahasiswa (Y).

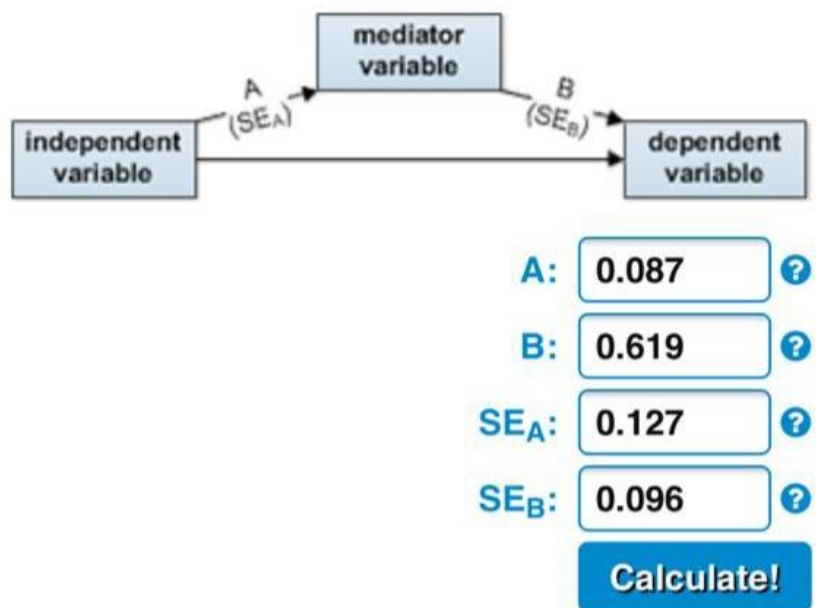

Sobel test statistic: $\mathbf{0 . 6 8 1 2 0 5 6 5}$

One-tailed probability: $\mathbf{0 . 2 4 7 8 7 0 6 9}$

Two-tailed probability: $\mathbf{0 . 4 9 5 7 4 1 3 7}$

Gambar 4.4 


\section{Uji Sobel Test Model 4}

Berdasarkan gambar 4.4 di atas menunjukkan hasil onetailled probality sebesar $0,24787069>0,05$, sehingga dapat disimpulkan variabel Prestasi Belajar (Z) tidak memediasi variebel Layanan jaminan (Assurance) X4 terhadap Kepuasan Mahasiswa $(Y)$.

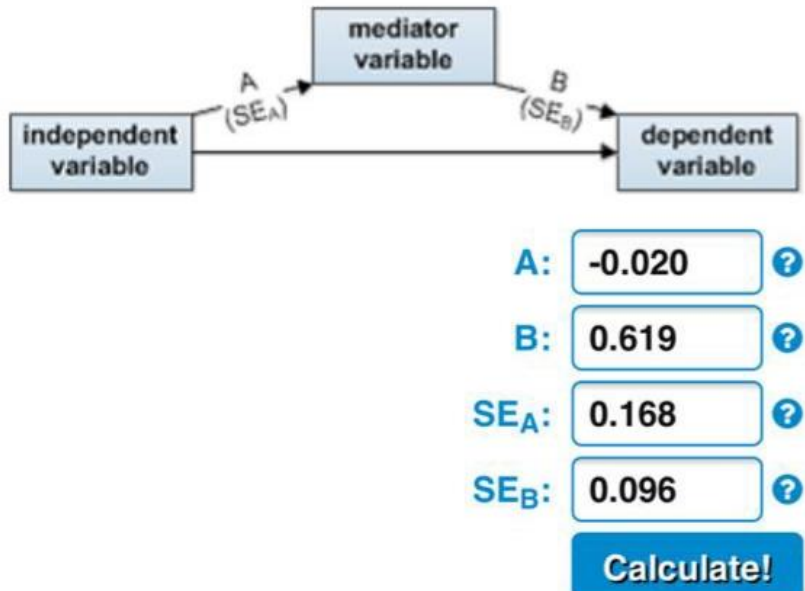

Sobel test statistic: $\mathbf{- 0 . 1 1 9 0 2 7 3 3}$

One-tailed probability: $\mathbf{0 . 4 5 2 6 2 6 8 5}$

Two-tailed probability: $\mathbf{0 . 9 0 5 2 5 3 7 0}$

\section{Gambar 4.5 \\ Uji Sobel Test Model 5}

Berdasarkan gambar 4.5 di atas menunjukkan hasil onetailled probality sebesar $0,45262685>0,05$, sehingga dapat disimpulkan variabel Prestasi Belajar (Z) tidak memediasi variebel Layanan Empati (Empathy) X5 terhadap Kepuasan Mahasiswa $(Y)$. 


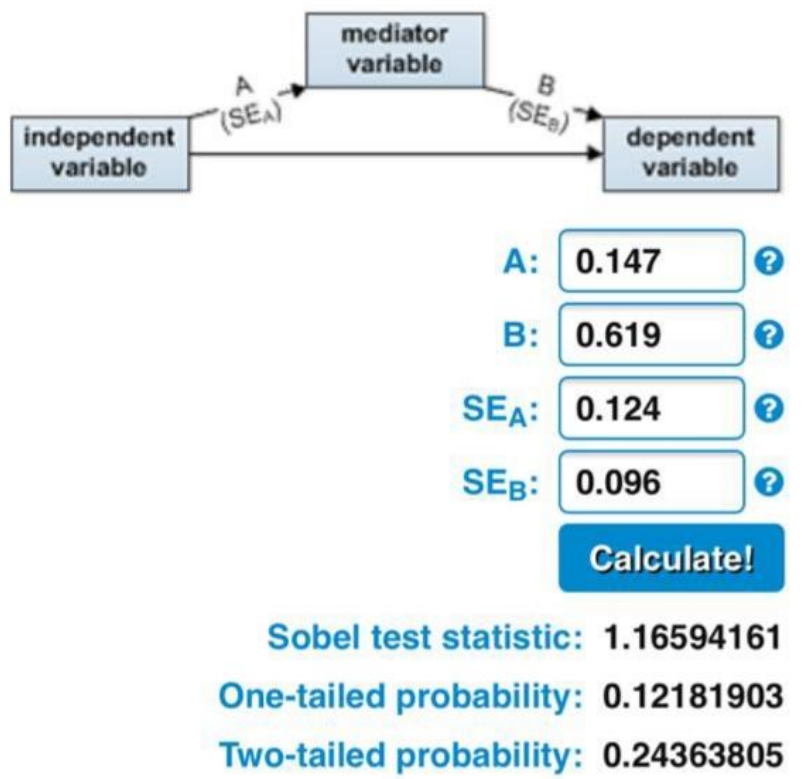

\section{Gambar 4.6 \\ Uji Sobel Test Model 6}

Berdasarkan gambar 4.6 di atas menunjukkan hasil onetailled probality sebesar 0,45262685 > 0,05, sehingga dapat disimpulkan variabel Prestasi Belajar (Z) tidak memediasi variebel Layanan System Informasi X6 terhadap Kepuasan Mahasiswa (Y).

\section{PEMBAHASAN}

\section{Kualitas Layanan (X) Terhadap Prestasi Belajar (Z)}

Hasil penelitian menunjukkan bahwa layanan fisik (tangible) $\mathrm{X} 1$, Layanan Ketanggapan (Responsive) X3, layanan jaminan (assurance) X4, Layanan Empati (empathy) X5 dan informasi system (X6) tidak berpengaruh dan tidak signifikan terhadap Prestasi Belajar.

Hasil penelitian menunjukkan bahwa Layanan Kehandalan (reability) X2 berpengaruh dan signifikan terhadap Prestasi Belajar.

\section{Pengaruh kuliasta layanan terhadap kepuasan mahasiswa}

Hasil penelitian menunjukkan bahwa layanan fisik (tangible) $\mathrm{X} 1$, layanan kehandalan (reability) X2, Layanan Ketanggapan (Responsive) X3, layanan jaminan (assurance) X4 dan Layanan Empati (empathy) X5 tidak berpengaruh dan tidak signifikan terhadap Kepuasan Mahasiswa.

Hasil penelitian menunjukkan bahwa Layanan informasi system berpengaruh dan signifikan terhadap Kepuasan Mahasiswa X6.

Pengaruh Prestasi Belajar (Z) Terhadap Kepuasan Mahasiswa (Y)

Hasil penelitian menunjukkan bahwa Prestasi Belajar berpengaruh dan signifikan terhadap Kepuasan Mahaiswa.

Pengaruh Kulitas Layanan (X) Terhadap Kepuasan Mahasiswa (Y) Melalui Mediasi Prestasi Belajar (Z) 
Prestasi Belajar (Z) Tidak Memediasi Pengaruh Kualitas Layanan layanan fisik (tangible) X1, Layanan Ketanggapan (Responsive) X3, layanan jaminan (assurance) $\mathrm{X} 4$, Layanan Empati (empathy) $\mathrm{X} 5$ dan informasi syst.em (X6) (X) Pada Kepuasan Mahasiswa (Y).

Prestasi Belajar (Z) Memediasi Pengaruh Kualitas Layanan Kehandalan (reability) X2 Pada Kepuasan Mahasiswa (Y).

\section{SIMPULAN DAN SARAN}

Hasil penelitian menunjukkan bahwa Layanan Kehandalan (reability) X2 berpengaruh dan signifikan terhadap Prestasi Belajar. Hasil penelitian menunjukkan bahwa Layanan informasi system berpengaruh dan signifikan terhadap Kepuasan Mahasiswa X6. Hasil penelitian menunjukkan bahwa Prestasi Belajar berpengaruh dan signifikan terhadap Kepuasan Mahaiswa. Prestasi Belajar (Z) Memediasi Pengaruh Kualitas Layanan Kehandalan (reability) X2 Pada Kepuasan Mahasiswa (Y).

\section{DAFTAR PUSTAKA}

Kamus besar Bahasa Indonesia. (Online), kbbi-id.cdn.amproject.org. diakses Juli 2019

Abdullah, F. (2006). The Development of HEDPERF: A New Measuring Instrument of Service Quality For The Higher Education Sector. International Journal Of Counseling Study, 569-581.

Aisyah, E. N. (2015). Statistik Inferensial Parametrik. Malang: Universiras Negeri Malang.

Al-Fatta, H. (2009). Analisis Dan Perangcangan Sistem Informasi Untuk Keunggulan Bersaing Perushaan Dan Organisasi Modern. Yogyakarta: Andi.

Amin, S. (2017). Strategi Peningkatan Kualitas Pelayanan Akademik Pada Perguruan Tinggi. Jurnal Madaniah, Volume 7.

Arifin, Z. (2009). Evaluasi Pembelajaran. Jakarta: Dirjen Pendidikan Islam Depag RI.

Arikunto. (2013). Prosedur Penelitian: Suatu Pendekatan Praktik. Jakarta: Rineka Cipta.

Asmara. (2009). Prestasi Belajar. Bandung: Remaja Rosdakarya.

Assauri, S. (2013). Mnajemen Pemasaran. Jakarta: Rajawali Pers.

Bahruddin, E. N. (2010). Teori Belajar Dan Pembelajaran. Yogyakarta: Arruzz Media.

Daryanto, I. S. (2014). Konsumen Dan Pelayanan Prima. Malang: Gaya Media.

Dede Cahyadi, P. N. (2012). Pengaruh Kualitas Pelayanan Sekretaris Terhadap Kepuasan Mahasiswa Program Studi Administrasi Bisnis Institusi Manajemen Telkom. Telkom University.

Evans Ojiambo Onditi, T. W. (2017). Service Quality And Student Satisfaction In Higher Education Institution: A Review Of Literature. 
International Journal Of Scientific And Research Publications, Vol. 7 (Issue 7).

Ghozali, I. (2012). Aplikasi Analisis Multivariate Dengan Program IBM SPSS. Yogyakarta: Universitas Diponegoro.

Ghozali, I. (2016). Aplikasi Analisis Multivariete Dengan Program IBM SPSS 23 (8 ed.). Semarang: Badan Penerbit Universitas Diponegoro.

Green, P. (2014). Measuring Service Quality In Higher Education: A South African Case Study. Journal Of International Education Research, Vol. 10 No. 2.

Griffin, J. (2010). Costumer Loyality, Menumbuhkan Dan Mempertahankan Kesetiaan Pelanggan. Jakarta: Erlangga.

Hamalik, O. (2011). Proses Belajar Mengajar. Jakarta: PT. Bumi Aksara.

Khattab, F. (2018). Developing A Service Qulity Model For Private Higher Education Institutions In Lebanon. Journal Of Management And Marketing Review.

Kotler, P. \&. (2014). Prinsip Prinsip Manajemen (14 Jilid 1 ed.). Jakarta: Erlangga.

Kriswandari, S. (2011). Faktor-Faktor Yang Mempengaruhi Kepuasan Konsumen Jasa Pendidikan Pada STIE Lampung. Manaemen Dan Bisnis, Volume 2, 1-15.

Lily Suhaily, Y. S. (2015). Factors Affecting Student Achievement. Journal The Winners, Vol. 16, 25-35.

Muhammad Fathurrahman, S. (2012). Belajar Dan Pembelajaran. Yogyakrta: Teras.

Nenden Anggi Rustami, N. T. (2016). Pengaruh Kualitas Jasa Pendidikan Terhadap Kepuasan Mahasiswa Di Universitas Pendidikan Indonesia. Jurnal ADPEND, 42-52.

Noer Rohmah. (2012). Psikologi Pendidikan. Yogyakarta: Teras.

Rahmawati, D. (2013). Analisis Faktor-Faktor Yang Mempengaruhi Kepuasan Mahasiswa. Jurnal Economia, Volume 9.

Ratna Suminar, M. A. (2017). Pelayanan Prima Pada Orang Tua Siswa di Sempoa SIP TC Paramount Summarecon. Jurnal Sekretari, 4.

Ratnasari, I. (2016). Pengaruh Kualitas Pelayanan Dan Citra Institusi Terhadap Kepuasan Mahasiswa Yang Berdampak Pada Word Of Mouth (Studi Kasus Pada Mahasiswa Universitas Singaperbangsa Karawang). Value Journal of Management and Business, Volume 1.

Reina. (2012). Faktor-Faktor Yang Mempengaruhi Kpeuasan Mahasiswa Pada Universitas Bina Nusantara. Binus Business Review, Vol. 3, 563-572.

Rudini, A. (2015). Pengaruh Kualitas Sistem, Kualitas Informasi Dan Kualitas Pelayanan SIA Terhadap Kepuasan Mahasiswa (Study Pada Mahasiswa STIE Sampit TA 2014-2015). Jurnal Terapan Manajemen dan Bisnis, 39-49.

Sanusi, A. (2011). Metode Penelitian Bisnis. Jakarta: Salemba Empat.

Sanusi, A. (2014). Metodelogi Penelitian Bisnis. Jakarta: Salemba Empat.

Sarjono, Y. (2007). Faktor-Faktor Strategik Pelayanan Dosen Dan Dampaknya Terhadap Kepuasan Mahasiswa FKIP Universitas 
Muhamadiyah Surakarta Tahun Akademik 2015-2016. Vardika, Vol. 19, 66-73.

Shaari, H. (2014). Service Quality in Malaysian Higher Education: Adult Learners' Perspective. International Journal Of Business And Social Science, Vol. 5 No. 1.

Siti Suminarti Fasikhah, S. F. (2013). SELF Regulated Learning (SRL) Dalam Meningkatkan Prestasi Akademik Pada Mahasiswa. Jurnal Ilmiah Psikologi Terapan, Vol. 01, 145-155.

Slameto. (2010). Belajar Dan Faktor-Faktor Yang Mempengaruhi. Jakarta: Renika Cipta.

Sopiatin, P. (2010). Manajemen Belajar Berbasis Kepuasan Siswa. Bogor: Ghalih Indonesia.

Sugiyono. (2012). Metode Penelitian Kuantitatif, Kualitatif dan R\&D. Bandung: Alfabeta.

Sugiyono. (2013). Metode Penelitian Kuantitatif, Kualitatif Dan R\&D. Bandung: ALFABETA.

Sugiyono. (2013). Metode Penelitian Kuantitatif, Kualitatif Dan R\&D. Bandung: ALFABETA.

Sugiyono. (2013). Metode Penelitian Kuantitatif, Kualitatif Dan R\&D. Bandung: ALFABETA.

Sugiyono. (2015). Metode Penelitian Kombinasi (Mix Methodes). Bandung: Alfabeta.

Sugiyono. (2016). Metode Penelitian Kuantitatif, Kualitatif Dan R\&D. Bandung: PT. Alfabet.

Sugiyono. (2017). Metode Penelitian Kuantitatif, Kualitatif, dan R\&D. Bandung: Alfabeta.

Sukandi, P. (2010). Hubungan Antara Fasilitas Kampus Terhadap Kepuasan Mahasiswa Dalam Menghadapi Daya Saing Jasa Pendidikan (Studi Kasus: Mahasiswa Fakultas Bisnis dan Manajemen Universitas Widyatama). PPM National Conference on Management Research.

Syah, M. (2010). Psikologi Pendidikan: Dengan Pendekatan Baru. Bandung: PT. Remaja Rosdakarya.

Tirtonegoro, S. (2001). Anak Super Normal dan Program Pendidikannya. Jakarta: Bina Aksara.

Tjiptono, F. (2014). Pemasaran Jasa-Prinsip, Penerapan dan Penelitian. Yogyakarta: Andi Offset.

Tjiptono, F. (2014). Pemasaran Jasa-Prinsip, Penerapan Dan Penelitian. Yogyakarta: Andi Offset.

Tjiptono, F. (2019). Pemasaran Jasa: Prinsip, Penerapan Dan Penelitian. Yogyakrta: ANDI. 